\title{
SUSTAINING COMPETITIVE ADVANTAGE THROUGH HRM: DEVELOPING STRATEGIC INTENT
}

\section{Priyanka Gupta}

Ph.D., Research Scholar, International Management Institute, New Delhi, priyanka.f19@imi.edu

\begin{abstract}
Purpose: This research consolidates existing literature and presents a conceptual framework for strategic human resources management (SHRM). The paper posits that SHRM provides sustained competitive advantage to organizations. Using the lens of 'strategic intent' the paper highlights how 'having strategic intent' can enable optimal implementation of HRM best practices and policies leading to implementation of strategic HRMand sustained competitive advantage for the organization.

Design: This research reviews existing theories in SHRM and uses a detailed case study based on Southwest airlines to highlight some best practices in HRM that make HRM strategic and provide sustained competitive advantage.

Findings:This research has used the lens of strategic intent to convey that HRM best practices can be successfully implemented when they integrate with organizational strategy and a mindset of strategic intent.

Originality:This research consolidates the existing literature and highlights some of the best practices in HRM and details how they provide sustained competitive advantage to the organization.

Implications: The findings in this research are significant and relevant for $H R$ professionals and senior business leaders as it signifies that HRM has economic value which compounds to create present and future worth for the organization and all its stakeholders.
\end{abstract}

Keywords: Strategic Human Resource Management (SHRM), Sustaining Competitive Advantage, Strategy, Strategic Intent, Southwest Airlines, Human Resources Management (HRM), Best Practices, High Performing Work Systems (HPWS)

"HR that starts with the business doesn't get as much resistance from the business" - Dave Ulrich

\section{Introduction}

The study of strategic human resources management SHRM(Ulrich, 1997; 1998; Ployhart and Hale, 2014; Ployhart, 2015; Schuler et al., 2017) necessitates a look at the brief history and definition of the term human resources management and organization behaviour. Theories based on sociology by the founding fathers; Emile Durkheim, Max Weber, and Karl Marx (Greenwood and Lawrence, 2005)confirm that the purpose of an organization is to create value from collective action and generate economic profit(Maas, 2019). Past and present management theory emphasizes thatto generate economic value firms must be strategic and compete with their socio-economic environment (Schulerand Jackson,1995; Ployhart, 2015).Porter 1985,contends that human resources are strategic(Ulrich, 1997; 1998; Ployhart, 2015) and can enable an organizationto gain competitive advantage (Lengnick-Hall and Lengnick-Hall,

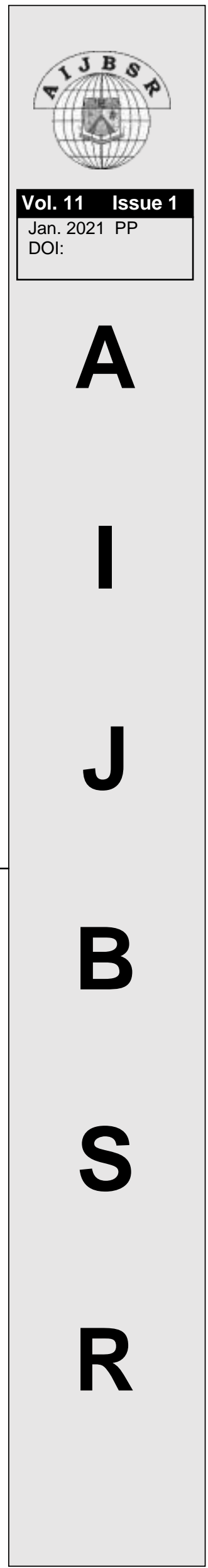

